\title{
Liquidity Analysis of Selected Public-Listed Companies in Malaysia
}

\author{
N. M. Baki Billah \\ Institute for Customer Relationship Management \\ 1-8, The Boulevard, Mid Valley City \\ Lingkaran Syed Putra, 59200 Kuala Lumpur, Malaysia \\ Tel: 601-8232-5274Ｅmail: jishan88@gmail.com
}

\author{
Noor Azuddin Jakob \\ UKM-Graduate School of Business, Universiti Kebangsaan Malaysia \\ 43600 Bangi, Selangor, Malaysia
}

Tel: 601-7608-5210 Email: azuddin@ukm.edu.my

Carl B. McGowan, Jr. (Corresponding Author)

Faculty Distinguished Professor and Professor of Finance, Norfolk State University

601 Pembroke Avenue, Norfolk, VA 23507, Malaysia

Tel: 757-275-6876 Email: cbmcgowan@yahoo.com

Received: September 22, 2014 Accepted: October 17, 2014 Published: March 30, 2014

doi:10.5296/ieb.v2i1.7508

URL: http://dx.doi.org/10.5296/ieb.v2i1.7508

\begin{abstract}
The Statement of Cash Flows is a crucial part of financial reporting. Thus, cash flow ratios have drawn the attention of practitioners and academic researchers to use to evaluate the performance of a company. This study examines, over the three years (2010-2012) period, the liquidity position of selected companies from three prominent sectors (Consumer products, Industrial products and Trading/Services) of the Malaysian economy using cash flow statement ratios and traditional liquidity ratios suggested by various researchers. Traditional ratios were obtained from the Osiris database and cash flow ratios were calculated by using
\end{abstract}




\section{Macrothink}

financial statements of selected companies. Traditional ratios examined were - current ratio, quick ratio, total asset to total liabilities ratio, and interest coverage ratio. Similarly, cash flow ratios examined were-operating cash flow ratio, critical needs cash coverage ratio, cash flow to total debt ratio, and cash interest coverage ratio. Correlation analysis was performed to investigate the strength of the relationship between traditional ratios and cash flow ratios. The empirical results of the correlation analysis show a statistically significant positive relationship between traditional ratios and cash flow ratios. Finally, pair t-tests results show that there is statistically significant difference between traditional ratios and cash flow ratios. The implication of the above empirical results suggests that traditional liquidity ratios should not be used solely for measuring liquidity since a company can have serious cash flow problems with positive liquidity ratios and increasing profits. Liquidity ratios developed using the statement of cash flows provide additional information or sometimes better insight on the financial strength or weakness of a company.

Keywords: Liquidity ratios, Cash flow ratios, Cash flow statement, Malaysian companies 


\section{Introduction}

Liquidity is an important financial indicator that measures whether the company has the ability to meet its short term liabilities (or not) without incurring undesirable losses. Due to ineffective use of assets, liquidity risk may arise which is obviously a most challenging risk compared to other financial risks. Subhanij (2010) believes that liquidity risk has become more complex because of recent developments in financial markets. Moreover, a liquidity crisis of a single company can affect, directly or indirectly, all the companies operating in the same industry. A company should maintain adequate liquidity to face unexpected conditions such as seasonal demand because it may not be able to acquire funds from external sources. If a liquidity shortfall arises, the company may not be able to meet obligations to suppliers, causing suppliers to stop delivery of raw materials which will hinder the production process, economies of scale cannot be achieved and cost of production will be increased. Therefore, a company may lose its market share due to scarcity of its product in market. In addition, banks will charge a higher interest rate because of a reduction in revenue or inadequate liquid assets of the company which may lead that company to bankruptcy.

A firm with adequate liquidity has greater financial flexibility so it can negotiate with suppliers and financiers (Note 1). The most significant story was about the Lehman Brothers collapse in 2008 when top management used current assets and invested in illiquid long term assets. When the stock market started to fall, Lehman's creditors cut credit lines and clients withdrew their funds and Lehman did not have liquid assets to meet short term obligations. Essentially, mismanagement of liquidity was one of the crucial reasons behind the bankruptcy of Lehman Brothers. Therefore, a company should have more current assets (cash, account receivable, inventories) than current liabilities (accounts payable, accrued liabilities) to maintain sound liquidity. In addition, smaller firms need to concentrate more on liquidity management as small firms have fewer potential sources of outside funds than large companies.

There are various methods for analyzing liquidity for a business enterprise. Current ratio and quick (acid test) ratio are commonly used to evaluate the short term liquidity of a business. For the long term solvency of a company, the total asset to total liability ratio is normally being used. However, Kirkham (2012) cautions that information for these ratios, which is obtained from the balance sheet, may not always be reliable due to various accounting measurement options of the values of assets and accrual accounting. As such, there is the need for a more accurate measure that reflects the actual liquidity position of a company.

Over the last two decades, Armen (2013) finds that the practice by financial researchers is to formulate cash flow ratios as the means of assessing the liquidity and solvency of a company. Generally, the emphasis is placed on the information derived from the statement of cash flows as it provides clearer picture to creditors, analysts and investors with regard to the company's cash flows position. Mills and Yamamura (1998) state that the statement of cash flows shows more reliable information for liquidity analysis than the balance sheet or income statement. This is because the statement of cash flows reports inflows and outflows of cash for a given period of time. Since operating, financing and investing activities are reported 
separately in that statement, Larson, Wild and Chappetta (2006) believe that the statement of cash flows can show a company's ability to finance its expenditure from operations, pay its existing debts as they mature and measure the company's ability to meet unexpected obligations and to pursue new business opportunities. The information from the statement of cash flows can be converted to ratios to analyze the financial position of a company.

One of the advantages that the statement of the cash flows holds over the balance sheet and income statement stems from the nature of financial reporting practice. Under accrual accounting (Note 2), the process of recording accounting information is done by considering both the effect of credit and cash transactions where financial transactions are recognized when they are incurred rather than solely focusing on when cash is received or cash is paid out. All assets or liabilities are recorded on the basis of original acquisition cost and depreciation or amortization is deducted from that original cost. In addition, revenues and expenses are recognized based on the matching concept. On this premise, Chotkunakitti (2005) sees a problem of recording cash only transactions especially when these transactions involve more than one period of recording since most companies usually deal with credit transactions.

The drawbacks of accrual accounting has resulted in the shift of attention to cash basis accounting where revenue is recognized when cash is received and expense is recognized when cash is paid. Cash flow accounting does not involve allocation and matching problems. Payments and receipts are recorded only when the transaction of receipts or payments are made. As such, Ali (1994) and Sharma (2001) feel that it is less possible to manipulate cash flow information compared to accrual information. Cash flow statement records information about the historical changes in cash or cash equivalents from operating, investing and financing activities of a company. A cash flow statement can be used to complement other financial statements to get comprehensive information regarding the changes of net assets and financial structure of an enterprise. The statement of cash flows helps users to gauge operating performance of different companies by eliminating the effects of using different accrual accounting treatments.

In the past, traditional balance sheet and income statement ratios are widely used by professionals and investors to analyze the liquidity of a company. However, the cash flow statement can be more reliable in assessing the liquidity of a company. Balance sheet, income statement and retained earnings statement do not provide an overall picture of the financial position of a company which is why the cash flow statement has become an essential component of complete financial reporting by professional accounting bodies (Note 3). According to Lee (1993), the statement of cash flows can overcome many limitations of accrual accounting procedures used to prepare traditional financial statements. For instance, balance sheet does not address the financing issues accurately at the end of the period. Even though many types of assets are shown in the statement, no explanation is given on the manner those assets were financed and/or the source of activities that are related to each item. Likewise, profit mentioned in the income statement does not provide any insight about changes in cash. In contrast, the cash flow statement details the dissimilarity between the operating profits of a firm and any increase or decrease in the cash balance over an 
accounting period. The statement of cash flows shows how the investing activities were financed, externally or internally. Knechel et al. (2007) posit that the cash flows statement helps to assess the capability of a company to generate future positive cash flows.

Gombola et al. (1987) assert that the information provided by the balance sheet and income statement can be misleading. Eyisi and Okpe (2014) provide evidence to support that claim. In their study, several cash flow ratios and traditional ratios adapted from previous research for assessing corporate performance were employed. They discover that although the traditional liquidity and asset management ratios provide evidence that suggest good liquidity position for a company, the cash basis ratios indicate that the liquidity position is indeed negative. Thus, they conclude that cash basis ratios can be better tools for assessing corporate performance as cash basis ratios provide better insight into the viability and liquidity position of a company. Other researchers such as Mills and Yamamura (1998), Armen (2013), Ryu and Jang (2004) as well as Eyisi and Okpe (2014) agree that traditional ratios such as current and quick ratio are not sufficient to assess the liquidity of a company.

Given the importance of liquidity for a company, it is necessary to determine the liquidity position of a company from many different dimensions. On that note, this study aims to examine the level of liquidity for selected Malaysian public-listed companies. It employs eight (8) different measures of liquidity for companies from three (3) different sectors, namely consumer products, industrial products and trade/services that are listed on Bursa Malaysia. The three (3) sectors are selected given their dominance in the stock exchange as can be seen from Table 1. The total number of companies listed in these three sectors represents over 65 percent of the market value of all listed companies on Bursa Malaysia. In addition to comparing the cash flow ratios with the traditional ratios using information from cash flow statement, balance sheet and income statement, the study seeks to establish the trend of liquidity among companies in these sectors. This study compares the level of liquidity for companies that are engaged in the three respective industries. The empirical results from this study can provide insight into the practice of liquidity management in companies in Malaysia. The paper is structured in the following format: the next section will present the literature review. This will be followed by the presentation of the data and the discussion on the methodology employed in this study. The next segment will present the empirical findings in addition the discussion of the result. Finally, the last part of the paper will present the conclusions of the paper.

Table 1. Number of companies listed in the main market of Bursa Malaysia

\begin{tabular}{|l|l|}
\hline Main Market/ACE Market & Total securities \\
\hline Consumer products & 135 \\
\hline Industrial products & 263 \\
\hline Mining & 1 \\
\hline Construction & 45 \\
\hline Trading/Services & 206 \\
\hline Properties & 87 \\
\hline
\end{tabular}




\begin{tabular}{|l|l|}
\hline Plantation & 42 \\
\hline Technology & 97 \\
\hline Infrastructure (IPC) & 7 \\
\hline Finance & 35 \\
\hline Hotels & 4 \\
\hline Closed-end fund & 1 \\
\hline Total & 923 \\
\hline
\end{tabular}

Source: Website of Bursa Malaysia as at June 28, 2013.

\section{Literature Review}

Financial ratios have been frequently used to evaluate a company's performance by different types of professionals. Andrew and Schmidgall (1993) state that financial ratios contain more valuable information for investors, creditors and managers than the absolute numbers found in the financial statements. Most traditional financial ratios are computed using data derived from the balance sheet and income statement for decision making purposes. Balance sheet reports present a picture of the company at a point in time and the income statement represents the results of business activities for a period of time. On the other hand, the cash flow statement reports crucial changes in activities over a period of time. By providing additional information, the statement of cash flow (SCF) provides additional useful information in addition to the information provided in the balance sheet and income statement. As such, cash flow ratios can provide supplementary insight to the traditional analysis.

Cash flow ratios are based on the cash flow from operations (CFO) of the company. Cash flow ratios are important measures of a company's financial success as a business is expected to operate profitably and generate cash. Otherwise insufficient cash can lead to default on accrued payables and ultimate bankruptcy, Bhandari and Iyer (2013). Carslaw and Mills (1991) posit that the cash flow ratios in conjunction with traditional balance sheet and income statement ratios can provide a clearer picture of financial strengths and weaknesses of a company. Cash flows from operations is the main component of cash flow ratios. It excludes the effect of non-cash flow items such as depreciation expenses and gains or losses on the sale of operating assets. As such, Kelly and O'Connor (1997) and Plewa and Friedlob (2002) suggest that ratios computed using the CFO are better measures of firm performance than traditional ratios obtained using data from the balance sheet and income statement. The same sentiment is shared by Giacomino and Mielke (1993) who feel that cash flow ratios provide more useful information in evaluating company's financial strength and profitability.

A study by Figlewicz and Zeller (1991) reveals that cash flow ratios provide supplementary information on a company's liquidity and financial performance in general, apart from the traditional approach to ratio analysis. However, Ryu and Jang (2004) discover conflicting results between traditional liquidity ratios and the CFO derived ratios. Kirkham (2012) report similar findings that suggest ambiguity between traditional liquidity ratios and the cash flow 
ratios. Therefore, decisions regarding liquidity should not be based solely on either traditional ratios or cash flow ratios alone. Instead, they both should complement one another to provide better insight of the liquidity position of a company.

In determining the liquidity of a company, the emphasis is normally given to the company's ability to meet short-term obligations. The current ratio and quick ratio are used for this purpose. Short term creditors such as suppliers and bankers are interested in evaluating company's liquidity position using these ratios (Note 4). According to Jagles and Coltman (2004), the ideal current ratio is $2: 1$ as it reflects the sufficient short-term financial resources that the company owns to match its short-term financial obligations. Short term creditors always prefer a higher current ratio as a higher current ratio shows a strong liquidity position of the company. In contrast, shareholders consider a high current ratio in the opposite way. A higher current ratio is not necessarily good since the higher current ratio might suggest that company has idle cash or marketable securities or excess inventory. Typically current assets consist of cash, marketable securities, accounts receivable and inventories. Needless to say, inventories are the least liquid of current assets since there is the possibility that they may become obsolete, thus causing the company to incur losses on obsolete inventories. This leads the way for the quick ratio which is used to measure the company's ability to pay off short term obligations without relying on inventories (Note 5).

However, operating cash flow ratios provide more reliable information about a company's ability to meet its payment commitments compared to the traditional balance sheet ratios such as the current ratio or quick ratio given that the balance sheet data are static (i.e. measuring a single point in time) and the income statement contains arbitrary non-cash items (e.g. depreciation and amortization). In other words, the current and quick ratio indicates how much cash the company had available on single date in the past. On the other hand, the statement of cash flows records the changes over a period of time in the other statements and focuses on cash available for operations and investments. Furthermore, Mills and Yamamura (1998) mention the failure of traditional ratios to investigate severe liquidity problems. For instance, positive current ratios and positive earnings have been reported based on the information from the annual reports even though the companies have severe negative cash flows. In addition, the traditional liquidity ratios are not capable to indicating the real financial situation when the company's current asset items are unusually large or small on a particular date. However, cash flow ratios can be used to overcome this problem. The numerator used in the calculation normally represents the net cash from operating activities adjusted for the non-cash items and changes in working capital while the denominator represents the actual current liabilities derived from balance sheet. Hence, it helps to avoid the distortion due to the unusual occurrence of current assets.

\section{Data and Methodology}

The study involved comparison between traditional ratios and newly contrived cash flow ratios of the top fifteen companies by market capitalization from three prominent sectors (i.e. consumer products, industrial products and trading services) on the Bursa Malaysia Main Market over a three year period (2010-2012). The consumer product companies are defined 
as those that are involved in manufacturing materials or components into new products for consumer use. The industrial product companies are defined as those that are involved in manufacturing materials or components into new products for industrial use. Companies that are engaged in the distribution of products and provision of services other than financial services (i.e. banking and insurance) are grouped under the trading/services sector. The reason behind choosing these three sectors is apparent given their dominance in the exchanges as shown in Table 1. In this study, a total of forty five companies were selected based on the following criteria:

1) must be listed in Bursa Malaysia,

2) must have complete data for all variables used in this study from 2010 to 2012, and

3) must represent the top fifteen companies by market capitalization in the selected three sectors.

Traditional ratios and financial statements for the three year period of the selected companies were obtained from the Osiris database. Cash flow ratios were calculated by focusing directly on cash flows from operating activities from the statement of cash flows. Earnings, total assets, total liabilities, current liabilities and other variables derived from income statement and balance sheet.

Exit barriers are high for companies with large market capitalizations. As a result, large companies are supposed to generate sufficient cash from operating activities to meet short and long term obligations. This study seeks to find any discrepancies between the two sets of ratios while analyzing traditional ratios versus cash flow ratios. Moreover, this study investigates ratios provide more reliable information about these big companies.

This study uses cash flow ratios and traditional ratios used in Ryu and Jang (2004) and Kirkham (2012) to measure performance based on liquidity and solvency. Table 4 presents formulas for traditional ratios and cash flow ratios employed in this study. Liquidity was measured by the current ratio and quick ratio and cash flow from operations to current liabilities and critical needs cash coverage ratio. Solvency was measured by total assets to total liabilities, time interest earned ratio, cash flow from operations to total liabilities and cash flow interest coverage.

Quantitative analysis is used in this study to analyze data based on statistical techniques: descriptive statistics and paired sample t-tests. Descriptive statistics provide an essential summary of the sample of this study. Pair sample t-tests were used to analyze paired differences between traditional ratios and cash flow ratios for selected companies. 
Table 4. Comparison of ratios

\begin{tabular}{|c|c|c|c|c|}
\hline \multicolumn{2}{|c|}{ Traditional Ratios } & \multicolumn{2}{c|}{ Cash Flow Ratios } & Formula \\
\hline Ratios & Formula & Ratio & CFO/CL & Leasure \\
\hline Current Ratio & CA/CL & CFO to CL & Liquidity \\
\hline Quick Ratio & (CA-Inventories)/CL & $\begin{array}{c}\text { Critical Needs cash } \\
\text { coverage }\end{array}$ & $\begin{array}{c}\text { (CFO + Interest Paid)/ (Total } \\
\text { current liabilities + Interest }\end{array}$ & Liquidity \\
\hline TA to TL ratio & TA/TL & CFO to TL & CFO/TL & Solvency \\
\hline $\begin{array}{c}\text { Interest Coverage } \\
\text { ratio }\end{array}$ & $\begin{array}{c}\text { EBIT/Interest } \\
\text { Expense }\end{array}$ & $\begin{array}{c}\text { Cash flow-interest } \\
\text { coverage }\end{array}$ & Taxes paid)/Interest paid & Solvency \\
\hline
\end{tabular}

Note. $* * \mathrm{CA}=$ Current assets, $\mathrm{CL}=$ Current liabilities, $\mathrm{TA}=$ total assets, $\mathrm{TL}=$ total liabilities, $\mathrm{EBIT}=$ earnings before interest and income tax, $\mathrm{CFO}=$ cash flow from operations.

Source: Adapted from (Ryu \& Jang, 2004), (Kirkham, 2012), (Mills \& Yamamura, 1998).

\section{Empirical Results and Discussion}

\subsection{Descriptive Statistics}

Descriptive Statistics were used to organize, summarize and display the research data in this study which includes all numerical values derived from the Osiris database and financial statements of selected companies. To analyze the characteristics of the variables, means, maximum, minimum and standard deviations were produced using SPSS. Descriptive statistics were analyzed separately for each type of ratios.

Table 5 shows that current ratio ranges from 0.42 to 11.72 . As discussed earlier, if the current ratio is lower than 1 then the company's liquidity position is weak. However, high current ratio is not always good as it shows the excess amount of cash or marketable securities or inventory. Noticeably, the mean of current ratio is 2.42 indicates a good liquidity position for most of the selected companies on average. The mean of operating cash flow ratio (0.69) is smaller than that of current ratio (2.42) which reflects the fact that the current ratio is calculated at a particular point in time whereas cash flow from operations is calculated by considering how much cash was generated over a period of time. Operating cash flow ratio ranges from -.22 to 6.56. Negative figure for operating cash flow ratio indicates that the company did not generate any cash from operation. There might be several good or bad reasons for this negative figure. But without further analysis, a negative operating cash flow ratio indicates that the company is in weak liquidity position with a negative operating cash flow ratio. Standard deviation is higher for current ratio (2.07) than that of operating cash flow ratio (0.81) which is because of ratios are more dispersed for current ratio than operating cash flow ratio. Both ratios are positively skewed. 
Table 5. Descriptive statistics of current ratio and cash flow ratio

\begin{tabular}{|l|c|c|c|c|c|c|c|c|}
\hline & $\mathrm{N}$ & Range & Minimum & Maximum & Mean & Std. Deviation & \multicolumn{2}{|c|}{ Skewness } \\
\cline { 2 - 9 } & Statistic & Statistic & Statistic & Statistic & Statistic & Statistic & Statistic & Std. Error \\
\hline Current ratio & 135 & 11.3000 & .4200 & 11.7200 & 2.418241 & 2.0757890 & 2.715 & .209 \\
\hline $\begin{array}{l}\text { Operating } \\
\text { Cash flow ratio }\end{array}$ & 135 & 6.7827 & -.2234 & 6.5593 & .693155 & .8116406 & 4.238 & .209 \\
\hline Valid N (listwise) & 135 & & & & & & & \\
\hline
\end{tabular}

Inventories are deemed to be least liquid amid other current assets. Hence, quick ratios are calculated by excluding inventories. Critical needs cash coverage ratio can be compared against quick ratio to gauge company's liquidity position. Interestingly, Table 6 shows that, maximum and minimum figures for quick ratio are quite close to that of current ratio (Table 5) which reflects selected companies did not have much inventory. In Table 6, maximum quick ratio (11.11) indicates that a company with high quick ratio has a lot of cash tied up in nonproductive asset presumably. Critical need cash coverage ratio ranges from -.15 to 6.12 , which is close to range of operating cash flow ratio (from Table 5) supports the evidence of previously explained liquidity position. The figure of both mean (.7) and standard deviation (.77) for critical needs cash coverage ratio is much lower than that of quick ratio (1.94 and 1.89 respectively). These differences again support the argument that cash flow ratios are calculated by directly focusing cash generated from operations.

Table 6. Descriptive statistics of quick ratio and critical needs cash coverage ratio

\begin{tabular}{|l|c|c|c|c|c|c|c|c|}
\hline & $\mathrm{N}$ & Range & Minimum & Maximum & Mean & Std. Deviation & \multicolumn{2}{|c|}{ Skewness } \\
\cline { 2 - 9 } & Statistic & Statistic & Statistic & Statistic & Statistic & Statistic & Statistic & Std. Error \\
\hline Quick ratio & 135 & 10.7136 & .3934 & 11.1071 & 1.936617 & 1.8948621 & 2.789 & .209 \\
\hline $\begin{array}{l}\text { Critical needs cash } \\
\text { coverage }\end{array}$ & 135 & 6.2723 & -.1547 & 6.1176 & .702163 & .7704606 & 4.062 & .209 \\
\hline Valid N (listwise) & 135 & & & & & & & \\
\hline
\end{tabular}

Equity investors and owners do not prefer high liquidity ratio as high liquidity indicates higher levels of cash or marketable securities or the holding of too much inventory which indicate a reason for losses. On the other hand, creditors prefer high current or quick ratio since it shows the company has good capability to pay off short term obligations. By looking the descriptive statistics of quick ratio, it can be concluded that selected companies had less 
inventory. That is, companies had the ability to pay short term obligations without relying on the sale of inventories. But it is important for managers to maintain balance between current assets and current liabilities. For a healthy firm, cash flow from operations to current liabilities should be a minimum 40 percent (Ryu \& Jang, 2004). In this study, the mean of cash flow from operations to current liabilities and critical needs cash coverage were higher than 40 percent which supports the result of current and quick ratios that most of companies have good position in terms of liquidity.

Total assets to total liabilities ratio is used to measure solvency of a company. Cash flow to total debt ratio is analogous to the traditional ratio (TA to TL). The higher the ratio is the greater the ability to cover losses during liquidation. Stockholders and creditors have as usual contradictory viewpoints in analyzing these two ratios. Particularly, total assets to total liabilities ratio is calculated at a single point in time; in contrast, cash flow to total debt ratio overcome this problem by covering a period of time (Mills \& Yamamura, 1998). Table 7 shows that the mean (3.26) of total assets to total liabilities is much higher than the mean (0.36) of cash flow to total debt ratio. Standard deviation of total assets to total liabilities ratio (3.15) is higher than that of cash flow to total debt ratio $(0.33)$ as well. The significant difference between these two ratios suggests that cash flow to total debt ratio is more reliable in assessing solvency as cash flow operations would be devoted to debt payments (Mills \& Yamamura, 1998). More precisely, even with higher total assets to total liabilities ratio a company may not have the capability to pay its debt, if the company has scarce cash flow from operation. Mean of selected companies for total assets to total liabilities shows good financial position; however, it needs to check whether those companies are generating adequate cash from operations or not. Higher total assets to total liabilities ratio is not desirable from the viewpoint of stockholders as they want companies to have more leverage in order to magnify expected earnings. Finally, creditors and equity investors need to compare these two ratios to have more reliable picture about the solvency of a company. For instance, a company with moderate total asset to total liabilities ratio and higher cash flow to total debt ratio can be more capable of paying debt compared to a company with higher total asset to total liabilities ratio and lower cash flow to total debt ratio (see Appendix A; PPB Group versus British American Tobacco Malaysia).

Table 7. Descriptive statistics of total assets to total liabilities ratio and cash flow to total debt ratio

\begin{tabular}{|l|c|c|c|c|c|c|c|c|}
\hline & $\mathrm{N}$ & Range & Minimum & Maximum & Mean & Std. Deviation & \multicolumn{2}{|c|}{ Skewness } \\
\cline { 2 - 9 } & Statistic & Statistic & Statistic & Statistic & Statistic & Statistic & Statistic & Std. Error \\
\hline TA to TL & 135 & 19.9745 & 1.1963 & 21.1708 & 3.257338 & 3.1451519 & 3.788 & .209 \\
\hline $\begin{array}{l}\text { Cash flow to total } \\
\text { debt ratio }\end{array}$ & 135 & 1.7919 & -.1033 & 1.6885 & .359879 & .3345898 & 1.649 & .209 \\
\hline Valid N (listwise) & 135 & & & & & & & \\
\hline
\end{tabular}


The interest coverage ratio measures company's ability to make required interest payment obligations. Earnings before interest and tax is used to pay interest expense. On the other hand, cash interest coverage ratio is similar to interest coverage ratio, which looks directly at the cash available to pay interest expense. The later one is more realistic since earnings figure includes all non-cash charges (e.g. amortization and depreciation etc.). A company with low interest coverage ratio may have the ability to make interest expenses but it may not be understandable by only looking at this traditional ratio due to non-cash charges (Mills \& Yamamura, 1998). Table 8 shows that, the mean and standard deviation of cash interest coverage ratio (105.3 and 297.41) are higher than the mean and standard deviation of interest coverage ratio (79.6 and 213.96) which reflects that earning figures were eroded by non-cash charges. Interesting to note that, minimum number for cash interest coverage ratio starts with negative $(-1.3)$; in contrast to that, minimum number for interest coverage ratio starts with positive figure (1.28). Negative figure indicates that the company had negative cash flow from operation; thus it would have less ability to cover interest obligations which could bring legal action by creditors. However, this realistic picture of true financial condition of a company is hard to get by only considering interest coverage ratio. Maximum figures for both ratios are too high because of insignificant amount of interest paid by the company against earnings before interest and tax or cash flow from operation (please refer to appendices, Top Glove Corporation).

Table 8. Descriptive statistics of interest cover ratio and cash interest coverage ratio

\begin{tabular}{|l|c|c|c|c|c|c|c|c|}
\hline & $\mathrm{N}$ & Range & Minimum & Maximum & Mean & \multicolumn{2}{c|}{ Std. Deviation } & \multicolumn{2}{|c|}{ Skewness } \\
\cline { 2 - 9 } & Statistic & Statistic & Statistic & Statistic & Statistic & Statistic & Statistic & Std. Error \\
\hline Interest Cover & 135 & 1980.0209 & 1.2800 & 1981.3009 & 79.579274 & 213.9577989 & 6.137 & .209 \\
\hline $\begin{array}{l}\text { Cash interest } \\
\text { coverage }\end{array}$ & 135 & 2648.1638 & -1.2965 & 2646.8673 & 105.295229 & 297.4087220 & 5.863 & .209 \\
\hline Valid N (listwise) & 135 & & & & & & & \\
\hline
\end{tabular}

\subsection{Correlation Analysis}

A measure of the correlation is represented by correlation coefficients. The coefficient provides both the direction and strength of the relationship between a pair of variables. In this study, the strength of association between all pairs of variables was statistically measured by Pearson's correlation coefficient. In statistics, Pearson's correlation coefficient measures linear correlation between two variables ranging from -1 to +1 , where 1 is total positive correlation, 0 is no correlation and -1 is total negative correlation. The correlations between pairs of cash flow ratios and traditional ratios are presented in Table 9. It can be seen that there are significant correlations between cash flow ratios and traditional ratios which reflects that if traditional ratios increase in value, cash flow ratios will also increase in value. Correlation figure of interest coverage ratio and cash interest coverage ratio demonstrates that there is strong relationship as Pearson's $r$ is 0.903 . This number is very close to 1 . However, 
there is relatively weak relationship between total assets to total liabilities ratio and cash flow to total debt ratio since the figure is 0.344 ; which is quite low compared to other pairs. The possible reasons would be capricious of accounting measurement of the values of assets and accrual accounting. Thus, by analyzing the strength of relationship between cash flow ratios and traditional ratios it can be concluded that these two type of ratios should be considered together to make better conclusion regarding the liquidity of a company.

Table 9. Pearson correlation coefficients of cash flow ratios and traditional ratios

\begin{tabular}{|c|c|c|c|}
\hline Pair 1 & $\begin{array}{c}\text { Current ratio and cash flow } \\
\text { ratio }\end{array}$ & 135 & 0.566 \\
\hline Pair 2 & $\begin{array}{c}\text { Quick ratio and critical } \\
\text { needs cash coverage ratio }\end{array}$ & 135 & 0.608 \\
\hline Pair 3 & $\begin{array}{c}\text { TA to TL ratio and Cash } \\
\text { flow to total debt ratio }\end{array}$ & 135 & 0.344 \\
\hline Pair 4 & $\begin{array}{c}\text { Interest coverage ratio and } \\
\text { Cash interest coverage ratio }\end{array}$ & 135 & 0.903 \\
\hline
\end{tabular}

\subsection{Test of Hypotheses}

Four hypotheses constructed in chapter 1 are discussed here for statistical test. Pair t-tests are used to measure the differences between pair of means for a pair of selected companies. In this study, data are paired data since two measurements (i.e. traditional ratios and cash flow ratios) are made on the same company. Traditional ratios and cash flow ratios were calculated for the selected of companies and Pair t-tests were used to identify significant difference between these two types of ratios.

Null Hypothesis 1: There is no significant difference between current ratio and cash flow ratio.

Alternate Hypothesis 1: There is significant difference between current ratio and cash flow ratio.

From Table 10, it can be seen that probability, p-value is less than 0.05 . Therefore, null hypothesis can be rejected and alternate hypothesis can be accepted. A two-tailed paired sample t-test revealed that there is significant difference between current ratio and cash flow ratio, $\mathrm{t}(134)=11.46, \mathrm{p} \leq 0.05$. Table 5 shows that, the mean of current ratio (2.42) is higher than that of cash flow ratio (0.69) which supports alternate hypothesis. 95\% Confidence Interval values are given in Table 10, which means, true population mean lies between 1.43 and 2.02 with a $95 \%$ probability. 


\section{Macrothink}

Table 10. Paired samples test of current ratio and cash flow ratio

\begin{tabular}{|c|c|c|c|c|c|c|c|c|c|}
\hline & \multicolumn{5}{|c|}{ Paired Differences } & \multirow{3}{*}{$\mathrm{t}$} & \multirow{3}{*}{$\mathrm{df}$} & \multirow{3}{*}{$\begin{array}{c}\text { Sig. } \\
\text { (2-tailed) }\end{array}$} \\
\hline & & \multirow[t]{2}{*}{ Mean } & \multirow{2}{*}{$\begin{array}{c}\text { Std. } \\
\text { Deviation }\end{array}$} & \multirow{2}{*}{$\begin{array}{l}\text { Std. Error } \\
\text { Mean }\end{array}$} & \multicolumn{2}{|c|}{$\begin{array}{c}95 \% \text { Confidence Interval of } \\
\text { the Difference }\end{array}$} & & & \\
\hline & & & & & Lower & Upper & & & \\
\hline $\begin{array}{c}\text { Pair } \\
1\end{array}$ & $\begin{array}{l}\text { Current ratio } \\
\text { - Cash flow } \\
\text { ratio }\end{array}$ & 1.7250853 & 1.7490107 & .1505309 & 1.4273614 & 2.0228091 & 11.460 & 134 & .000 \\
\hline
\end{tabular}

Null Hypothesis 2: There is no significant difference between quick ratio and critical needs cash coverage ratio.

Alternate Hypothesis 2: There is significant difference between quick ratio and critical needs cash coverage ratio.

From Table 11, it can be seen that probability, p-value is less than 0.05 . Therefore, null hypothesis can be rejected and alternate hypothesis can be accepted. A two-tailed paired sample t-test revealed that there is significant difference between quick ratio and critical needs cash coverage ratio, $\mathrm{t}(134)=9.24, \mathrm{p} \leq 0.05$. Table 6 shows that, the mean of quick ratio (1.94) is higher than that of critical needs cash coverage ratio (0.702) which supports alternate hypothesis. 95\% Confidence Interval values are given in Table 11, which means, true population mean lies between 0.97 and 1.5 with a $95 \%$ probability.

Table 11. Paired samples test of quick ratio and critical needs cash coverage ratio

\begin{tabular}{|c|c|c|c|c|c|c|c|c|c|}
\hline & \multicolumn{5}{|c|}{ Paired Differences } & \multirow{3}{*}{$\mathrm{t}$} & \multirow{3}{*}{$\mathrm{df}$} & \multirow{3}{*}{$\begin{array}{c}\text { Sig. } \\
\text { (2-tailed) }\end{array}$} \\
\hline & & \multirow[t]{2}{*}{ Mean } & \multirow{2}{*}{$\begin{array}{c}\text { Std. } \\
\text { Deviation }\end{array}$} & \multirow{2}{*}{$\begin{array}{c}\text { Std. Error } \\
\text { Mean }\end{array}$} & \multicolumn{2}{|c|}{$\begin{array}{c}95 \% \text { Confidence Interval } \\
\text { of the Difference }\end{array}$} & & & \\
\hline & & & & & Lower & Upper & & & \\
\hline $\begin{array}{c}\text { Pair } \\
1\end{array}$ & $\begin{array}{l}\text { Quick ratio - } \\
\text { Critical needs } \\
\text { cash coverage }\end{array}$ & 1.2344540 & 1.5522914 & .1336000 & .9702166 & 1.4986915 & 9.240 & 134 & .000 \\
\hline
\end{tabular}

Null Hypothesis 3: There is no significant difference between total assets to total liabilities ratio and cash flow to total liabilities ratio.

Alternate Hypothesis 3: There is significant difference between total assets to total liabilities ratio and cash flow to total liabilities ratio.

From Table 12, it can be seen that probability, p-value is less than 0.05 . Therefore, null hypothesis can be rejected and alternate hypothesis can be accepted. A two-tailed paired sample t-test revealed that there is significant difference between total assets to total liabilities 
ratio and cash flow to total liabilities ratio, $\mathrm{t}(134)=11.051, \mathrm{p} \leq 0.05$. Table 7 shows that, the mean of total assets to total liabilities ratio (3.26) is higher than that of cash flow to total liabilities ratio (0.36) which supports alternate hypothesis. 95\% Confidence Interval values are given in Table 12, which means, true population mean lies between 2.38 and 3.42 with a $95 \%$ probability.

Table 12. Paired Samples Test of total assets to total liabilities ratio and cash flow to total liabilities ratio

\begin{tabular}{|c|c|c|c|c|c|c|c|c|c|}
\hline & \multicolumn{5}{|c|}{ Paired Differences } & \multirow{3}{*}{$\mathrm{t}$} & \multirow{3}{*}{ df } & \multirow{3}{*}{$\begin{array}{c}\text { Sig. } \\
\text { (2-tailed) }\end{array}$} \\
\hline & & \multirow{2}{*}{ Mean } & \multirow{2}{*}{$\begin{array}{c}\text { Std. } \\
\text { Deviation }\end{array}$} & \multirow{2}{*}{$\begin{array}{c}\text { Std. Error } \\
\text { Mean }\end{array}$} & \multicolumn{2}{|c|}{$\begin{array}{c}95 \% \text { Confidence Interval } \\
\text { of the Difference }\end{array}$} & & & \\
\hline & & & & & Lower & Upper & & & \\
\hline $\begin{array}{c}\text { Pair } \\
1\end{array}$ & $\begin{array}{l}\text { TA to TL - } \\
\text { Cash flow to } \\
\text { total debt } \\
\text { ratio }\end{array}$ & 2.8974588 & 3.0462419 & .2621788 & 2.3789149 & 3.4160027 & 11.051 & 134 & .000 \\
\hline
\end{tabular}

Null Hypothesis 4: There is no significant difference between interest coverage ratio and cash interest coverage ratio.

Alternate Hypothesis 4: There is significant difference between interest coverage ratio and cash interest coverage ratio.

From Table 13, it can be observed that probability; p-value is less than 0.05 . Therefore, null hypothesis can be rejected and alternate hypothesis can be accepted. A two-tailed paired sample t-test revealed that there is significant difference between interest coverage ratio and cash interest coverage ratio, $\mathrm{t}(134)=-2.15, \mathrm{p} \leq 0.05$. 95\% Confidence Interval values are given in Table 13, which means, true population mean lies between -49.37 and -2.06 with a $95 \%$ probability.

Table 13. Paired samples test of interest coverage ratio and cash interest coverage ratio

\begin{tabular}{|c|c|c|c|c|c|c|c|c|c|}
\hline & \multicolumn{5}{|c|}{ Paired Differences } & \multirow{3}{*}{$\mathrm{t}$} & \multirow{3}{*}{$\mathrm{df}$} & \multirow{3}{*}{$\begin{array}{c}\text { Sig. } \\
\text { (2-tailed) }\end{array}$} \\
\hline & & \multirow{2}{*}{ Mean } & \multirow{2}{*}{$\begin{array}{c}\text { Std. } \\
\text { Deviation }\end{array}$} & \multirow{2}{*}{$\begin{array}{l}\text { Std. Error } \\
\text { Mean }\end{array}$} & \multicolumn{2}{|c|}{$\begin{array}{c}95 \% \text { Confidence Interval } \\
\text { of the Difference }\end{array}$} & & & \\
\hline & & & & & Lower & Upper & & & \\
\hline $\begin{array}{c}\text { Pair } \\
1\end{array}$ & $\begin{array}{l}\text { Interest Cover } \\
\text { - Cash interest } \\
\text { coveragae }\end{array}$ & -25.7159545 & 138.9831921 & 11.9617686 & -49.3742486 & -2.0576604 & -2.150 & 134 & .033 \\
\hline
\end{tabular}




\section{Summary and Conclusions}

\subsection{Conclusions}

Cash flow ratios are undeniably important for both internal and external users since these ratios provide more reliable information about a company's ability to meet its payment obligations than do traditional ratios. The major benefit of cash flow ratios is that these ratios test what resources the company has generated to meet its payment commitments over a period of time. In contrast, traditional ratios provide misleading information as these ratios indicate how much cash the company had available on single point of time.

This study tested the use of cash flow ratios to measure liquidity by comparing with relevant traditional ratios. The empirical result showed statistical significant difference between these two types of ratios. In most cases cash flow ratios supported traditional ratios by providing additional insight in this research. Therefore, it is recommended to use these two types of ratios simultaneously in order to make conclusion about a firm's financial strength or weakness.

\subsection{Limitations of the Study and Suggestion for Future Research}

This study focused solely on top fifteen companies by market capitalization from three prominent sectors of Bursa Malaysia, thus it may affect generalizability of this research. Consequently, the findings may not apply to other sectors of Bursa Malaysia. The time period of this study is three years (2010-2012) and number of selected companies was forty five due to time constraint. The major problem with cash flow ratios is when company doesn't generate any cash from operating activities then cash flow ratios become negative which then make comparison complicated. This study used few of the cash flow ratios; therefore, future study can be benefitted by using a greater number of cash flow ratios.

Future study can be done by employing more sectors from Bursa Malaysia to compare the liquidity performance using traditional ratios and cash flow ratios. Moreover, further research may include liquidity assessment of specific industry (e.g. airline industry) of a developing country with those of a developed country using cash flow ratios and traditional ratios.

\section{References}

Ali, A. (1994). The incremental information content of earnings, working capital from operations, and cash flows. Journal of Accounting Research, 32(1), 61-74.

Andrew, W. P., \& Schmidgall, R. S. (1993). Financial management for the hospitality industry. Lansing, MI: Educational Institute of the American Hotel \& Lodging Association.

Armen, S. (2013). Performance assessment of major U.S. airlines via cash flow ratios. Annals of the University of Oradea, Economic Science Series, 22(2), 398-408.

Azadinamin, A. (2012). The Bankruptcy of Lehman Brothers: Causes of Failure \& Recommendations Going Forward. 
Birgham, E. F., \& Ehrhardt, M. C. (2007). Analysis of Financial Statements. Financial Management: Theory and Practice, 442-451.

Bhandari, S. B., \& Iyer, R. (2013). Predicting business failure using cash flow statement based measures. Managerial Finance, 39(7), 667-676.

Bursa, M. (2013). Classification of Bursa Malaysia Sectors, Malaysia. Retrieved June 12, 2014 from http://www.bursamalaysia.com/misc/regulation_rules_main_market_bm_main_sector_ classification.pdf

Carslaw, C. A., \& Mills, J. R. (1991). Developing ratios for effective cash flow statement analysis. Journal of Accountancy, 172(5), 63-68.

Chotkunakitti, P. (2005). Cash flows and accrual accounting in predicting future cash flows of Thai listed companies. DBA thesis, Southern Cross University, Lismore, NSW.

Coltman, M. M., \& Jagels, M. G. (2001). Hospitality management accounting (7th ed.). NewYork: Wiley.

CPA Australia. (2010). Guide to managing liquidity risk. CPA Australia. Retrieved from

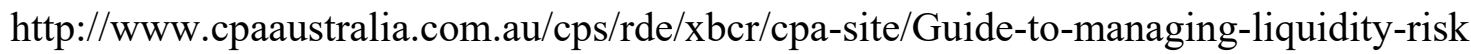
.pdf

Eyisi, A. S., \& Okpe, I. I. (2014). The Impact of Cash Flow Ratio on Corporate Performance. Research Journal of Finance and Accounting, 5(6). Retrieved from http://www.iiste.org/Journals/index.php/RJFA/article/view/11922

Figlewicz, R. E., \& Zeller, T. L. (1991). An analysis of performance, liquidity, coverage and capital ratios from the statement of cash flows. Akron Business and Economics Review, 22(1), 64-81.

Fox, J. (2009). Three lessons of the Lehman Brothers collapse. Time. Retrieved from http://www.time.com/time/business/article/0,8599,1923197,00.html

Giacomino, D. E., \& Mielke, D. E. (1993). Cash flows: Another approach to ratio analysis. Journal of Accountancy, 175(3), 55-58.

Godfrey, J. M., Hodgson, A., \& Holmes, S. (2003). Accounting Theory (5th ed.). Milton, Queensland: John Wiley \& Sons Australia.

Gombola, M. J. \& Ketz, J. E. (1983a). A note on cash flow and classification patterns of financial ratios. The Accounting Review, 58(1), 105-114.

Gombola, M. J., Haskins, M. E., Ketz, J. E., \& Williams, D. D. (1987). Cash flow in bankruptcy prediction. Financial Management, 16(4), 55-65.

Jagles, M. G., \& Coltman, M. M. (2004). Hospitality management accounting (8th ed.). New York: Wiley. 
Kelly, J., \& O'Connor, J. (1997). Is profit more important than cash flow? Management Accounting, 75(6), 28-29.

Knechel, W., Salterio, R., Steven, E., Ballou, E., \& Brian, A. (2007). Auditing: assurance \& risk. Canada: Thompson South-Western.

Kimmel, P. D., Weygandt, J. J., \& Kieso, D. E. (2000). Financial Accounting: Tools for Business Decision Making. New York: John Wiley\& Sons, Inc.

Kirkham, R. (2012). Liquidity Analysis Using Cash Flow Ratios and Traditional Ratios: The Telecommunications Sector in Australia. Journal of New Business Ideas \& Trends, 10, $1-13$.

Larson, K. D., Wild, J. J., \& Chiappetta, B. (2006). Fundamental accounting principles (17th ed.). New York: McGraw-Hill.

Lee, T. A. (1993). Cash Flow Reporting: A Recent History of an Accounting Practice. New works in Accounting History, Garland Pub, New York.

Malaysian Accounting Standards Board. (1996). Cash Flow Statements. Retrieved from http://www.masb.org.my/index.php?option=com_content\&view $=$ article\&id=629:masb 5-cash-flow-statements-pg $1 \&$ catid=7:masb-for-private

Mills, J. R., \& Yamamura, J. H. (1998). The power of cash flow ratios. Journal of Accountancy, 186(4), 53-61.

Plewa, F. J., \& Friedlob. (2002). New ways to analyze cash flows. National Public Accountant, 47(1), 25-43.

Ryu, K., \& Jang, S. (2004). Performance Measurement Through Cash Flow Ratios and Traditional Ratios: A Comparison of Commercial and Casino Hotel Companies. Journal of Hospitality Financial Management, 12(1). Retrieved from http://scholarworks.umass.edu/jhfm/vol12/iss1/3

Salmi, T., Virtanen, I., \& Yli-Olli, P. (1990). On the classification on financial ratios: A factor and transformation analysis of accrual, cash flow, and market-based ratios. Acta Wasaensia, 25.

Schimidgall, R. S., Geller, A. N., \& Ilvento, C. (1993). Financial analysis using the statement of cash flows. Cornell Hotel and Restaurant Administration Quarterly, 34(I), 46-53.

Sharma, D. S. (2001). The role of cash flow information in predicting corporate failure: The state of the literature. Managerial Finance, 27(4), 3-28.

Subhanij, T. (2010). Liquidity management and measurement in the SEACEN countries. Retrieved from http://www.seacen.org/GUI/pdf/publications/research_proj/2010/RP81/RP81_complete .pdf 
Weygandt, J. J., Kieso, D. E., \& Kimmel, P. D. (1998). Financial accounting (2 ${ }^{\text {nd }}$ ed.). New Jersey: John Wiley \& Sons.

Yli-Olli, P., \& Virtanen, I. (1989). On the long-term stability and cross-country invariance of financial ratio patterns. Journal of Operational Research, 39(1), 40-53.

\section{Notes}

Note 1. See CPA Australia (2010).

Note 2. See Godfrey, Hodgson and Holmes (2003).

Note 3. See Kimmel, Weygandt and Kieso (2000).

Note 4. See Weygandt, Kieso and Kimmel (1998).

Note 5 See Brigham and Ehrhardt (2007).

\section{Appendix A. List of Selected Top Fifteen Companies by Market Capitalization}

\begin{tabular}{|c|c|c|}
\hline No. & Constituent name & Sector \\
\hline 1 & Petronas Dagangan Bhd & Trading/Services \\
\hline 2 & SapuraKencana Petroleum & Trading/Services \\
\hline 3 & Malaysia International Shipping Corporation & Trading/Services \\
\hline 4 & Sime Darby Bhd & Trading/Services \\
\hline 5 & Genting & Trading/Services \\
\hline 6 & Axiata Group Bhd & Trading/Services \\
\hline 7 & Maxis Bhd & Trading/Services \\
\hline 8 & Tenaga Nasional & Trading/Services \\
\hline 9 & YTL Corporation & Trading/Services \\
\hline 10 & Telekom Malaysia & Trading/Services \\
\hline 11 & Malaysia Airports Holdings Bhd & Trading/Services \\
\hline 12 & Dialog Group Bhd & Trading/Services \\
\hline 13 & MMC Corporation Bhd & Trading/Services \\
\hline 14 & Hap Seng Consolidated Berhad & Trading/Services \\
\hline 15 & Genting Malaysia BHD & Trading/Services \\
\hline 16 & PPB Group & Consumer \\
\hline 17 & British American Tobacco (Malaysia) & Consumer \\
\hline 18 & UMW Holdings & Consumer \\
\hline 19 & Oriental Holdings Bhd & Consumer \\
\hline 20 & Guinness Anchor Berhad & Consumer \\
\hline 21 & Tan Chong Motor Holdings Berhad & Consumer \\
\hline 22 & Hong Leong Industries Berhad & Consumer \\
\hline 23 & Carlsberg Brewery Malaysia Berhad & Consumer \\
\hline 24 & Fraser \& Neave Holdings Bhd & Consumer \\
\hline
\end{tabular}




\begin{tabular}{|l|c|c|}
\hline 25 & Nestle (Malaysia) Berhad & Consumer \\
\hline 26 & Bonia Corporation Bhd & Consumer \\
\hline 27 & Ntpm Holdings Berhad & Consumer \\
\hline 28 & Ql Resources Bhd & Consumer \\
\hline 29 & Padini Holdings Berhad & Consumer \\
\hline 30 & Malayan Flour Mills Bhd & Consumer \\
\hline 31 & Petronas Gas & Industrial Products \\
\hline 32 & Petronas Chemicals Group Bhd & Industrial Products \\
\hline 33 & Drb-Hicom Bhd & Industrial Products \\
\hline 34 & Cahya Mata Sarawak Bhd & Industrial Products \\
\hline 35 & Hartalega Holdings Bhd & Industrial Products \\
\hline 36 & Kossan Rubber Industries Bhd & Industrial Products \\
\hline 37 & Keck Seng (M) Bhd & Industrial Products \\
\hline 38 & Lafarge Malaysia Berhad & Industrial Products \\
\hline 39 & Top Glove Corporation Bhd & Industrial Products \\
\hline 40 & Jaya Tiasa Holdings Bhd & Industrial Products \\
\hline 41 & Coastal Contracts Bhd & Industrial Products \\
\hline 42 & Press Metal Bhd & Industrial Products \\
\hline 43 & Ta Ann Holdings Berhad & Industrial Products \\
\hline 44 & Tasek Corporation Bhd & Industrial Products \\
\hline 45 & Supermax Corporation Bhd & Industrial Products \\
\hline & &
\end{tabular}

\section{Copyright Disclaimer}

Copyright for this article is retained by the author(s), with first publication rights granted to the journal. This is an open-access article distributed under the terms and conditions of the Creative Commons Attribution license (http://creativecommons.org/licenses/by/3.0/). 